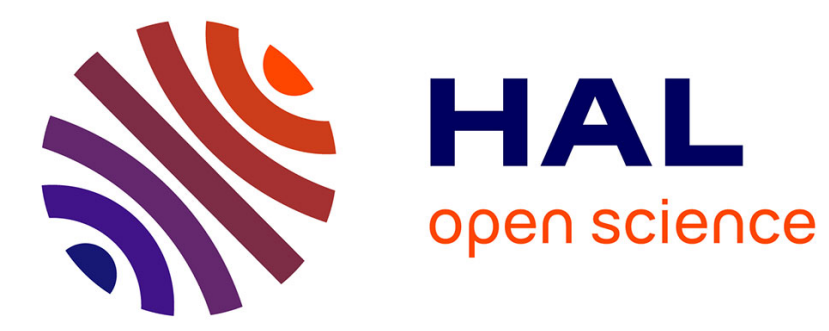

\title{
Book Review: Henri Lefebvre, Rhythmanalysis: Space, Time and Everyday Life
}

\author{
Dave Horton
}

\section{To cite this version:}

Dave Horton. Book Review: Henri Lefebvre, Rhythmanalysis: Space, Time and Everyday Life. Time \& Society, 2005, 14 (1), pp.157-159. 10.1177/0961463X0501400105 . hal-00570983

\section{HAL Id: hal-00570983 \\ https://hal.science/hal-00570983}

Submitted on 1 Mar 2011

HAL is a multi-disciplinary open access archive for the deposit and dissemination of scientific research documents, whether they are published or not. The documents may come from teaching and research institutions in France or abroad, or from public or private research centers.
L'archive ouverte pluridisciplinaire HAL, est destinée au dépôt et à la diffusion de documents scientifiques de niveau recherche, publiés ou non, émanant des établissements d'enseignement et de recherche français ou étrangers, des laboratoires publics ou privés. 


\section{References}

Adams, C. J. (1997) 'Mad Cow Disease and the Animal Industrial Complex. An Ecofeminist Analysis', Organisation \& Environment 10(1).

Bravermann, H. (1974/1999) Labor and Monopoly Capital: The Degradation of Work in the Twentieth Century. New York: Monthly Review Press.

Corradi, L. (1991/2003) Il tempo rovesciato. Milano: Angeli.

Corradi, L. (1998) 'Le città just-in-time. Per una critica del tempo neoliberale', in G. Paolucci (ed.) La città macchina del tempo. Milano: Angeli.

Harvey, D. (1990) The Condition of Postmodernity: an Enquiry Into the Origins of Cultural Change. Cambridge: Blackwell.

Hochschild, A. R. (1997) The Time Bind: When Work Becomes Home and Home Becomes Work. New York: Metropolitan Books.

Leccardi, C. (1996) Futuro breve. Torino: Rosenberg \& Sellier.

Odih, P. (2003) 'Gender, Work and Organization in the Time/Space Economy of Just in Time Labour', Time \& Society 12(2/3): 293-314.

Rubin, L. (1976/1992) Worlds of Pain. Life in the Working Class Family. New York: Basic Books.

Southerton, D. (2003) 'Squeezing Time. Allocating Practices, Coordinating Networks and Scheduling Society', Time \& Society 12(1): 5-25.

Laura Corradi, University of Calabria, Arcavacata, Italy

Henri Lefebvre, Rhythmanalysis: Space, Time and Everyday Life. London and New York: Continuum, 2004. 160 pp. ISBN 0826469930, £55 (hbk); $0826472990, £ 15.99$ (pbk).

This little book brings together Henri Lefebvre's key writings on time, in English, for the first time. Rythmanalysis contains the first full English translation of Éléments de rythmanalyse, published in 1992, shortly after Lefebvre's death, together with two earlier essays, jointly written with his last wife Catherine Régulier, 'The Rhythmanalytical Project' and 'Attempt at the Rhythmanalysis of Mediterranean Cities'. In sum, it provides the most thorough account of Lefebvre's work on time yet available to an English-speaking audience and, as such, it really demands to be read.

In an insightful introduction, Stuart Elden, Lefebvre scholar and one of the book's translators, suggests that the recent emphasis, among anglophone scholars at least, on Lefebvre's work on space has been to the detriment of his lifelong concern with time and, more especially, the conjunction of time and space in rhythm. Rhythmanalysis redresses this imbalance, making clear that Lefebvre was a theorist of time as much as of space and, above all else, insisted on the importance of thinking space and time together: spaces are timed; times are spaced. The clearest articulation of one of Lefebvre's key points is provided late in the book, in the co-authored 'Attempt at the Rhythmanalysis of Mediterranean Cities': 
concrete times have rhythms, or rather are rhythms - and all rhythms imply the relation of a time to a space, a localised time, or, if one prefers, a temporalised space. Rhythm is always linked to such and such a place, to its place, be that the heart, the fluttering of the eyelids, the movement of a street or the tempo of a waltz. This does not prevent it from being a time, which is to say an aspect of a movement or of a becoming. (p. 89)

Lefebvre wants to develop our awareness and appreciation of rhythms, to advocate rhythmanalysis as a vocation. The apprentice rhythmanalyst must listen to her body, 'learn rhythm from it, in order consequently to appreciate external rhythms' (p. 19). She "will come to "listen" to a house, a street, a town, as an audience listens to a symphony' (p. 22). For the world is moving, everywhere and everything, without exception, is rhythm. In the first chapter, 'The Critique of the Thing', Lefebvre declares: "nothing inert in the world, no things: very diverse rhythms, slow or lively (in relation to $u s$ )' (p. 17). If the rhythmanalyst 'considers a stone, a wall, a trunk, he understands their slowness, their interminable rhythm' (p. 20).

The new rhythmanalysts would be the standard-bearers of the science which it is the book's stated ambition to found. Although some social scientists - Barbara Adam springs quickly to mind - are clearly pursuing something akin to the kind of rhythmanalysis advocated by Lefebvre, it is obviously not necessary to become a strict rhythmanalyst to see the benefits of thinking and analysing rhythmically. Because what Rhythmanalysis does, and very successfully, is to increase the reader's sensitivity to the diverse, multiple rhythms of everyday life. The concrete rhythmanalysis of a Parisian junction seen from Lefebvre's apartment window, brings to mind speeded-up cinematic footage of the incessant flows of urban life, with cars and pedestrians alternately waiting and then streaming across road intersections. Description of the rhythms of trees across the seasons - the comings and goings of leaves, flowers, fruit and seeds - is another reminder that rhythms surround us, if only we pay attention, with all our senses. It's certainly the case that, having engaged with this work, I'm more consciously listening, attending, to the trains passing in the night, the car engines coming to life and the shouts of school children at the start of the day, and - as I settle at my desk - the street falling quiet again once the early morning peak in noise subsides. Lefebvre's work encourages rhythmanalysis as a sensibility, as close to the poetic as the scientific. The rhythmanalyst is 'more sensitive to times than to spaces, to moods than to images, to the atmosphere than to particular events' (p. 87).

Rhythms have specific characteristics, which Lefebvre explores. Wherever time, space and an expenditure of energy coincide, there is rhythm (p. 15). Rhythm is always relative; faster rhythms imply slower rhythms, and vice versa. Silence is a rhythm as much as the noise of hubbub, which the rhythmanalyst can dissect to identify the specific rhythms of which it is composed. Rhythms are about repetition, yet repetition produces difference. We need to be outside of rhythms to notice and analyse rhythms (p. 88). Usually taken for granted, rhythms become clearer with their breakdown, the onset of arrhythmia. It is when providing specific insights into the workings and analysis of rhythms that I think Lefebvre is at his best. His 
rhythmanalysis urges us towards a more cadenced understanding of the worlds, whichever worlds, we choose to investigate.

Lefebvre's is never a naïve analysis of rhythms, of course. The Marxist roots of his analysis are rarely far from the surface, he never loses sight of how everyday rhythms are produced elsewhere as well as here, by what is not obviously present (though embedded in architecture, in space), by the structuring rhythms of the state and capital. For Lefebvre, humans are produced both by 'natural' rhythms of respiration and the heart and the 'social' rhythms of contemporary cultural processes. These rhythms converge on the body, in 'the everyday'. 'The everyday is simultaneously the site of, the theatre for, and what is at stake in a conflict between great indestructible rhythms and the processes imposed by the socio-economic organisation of production, consumption, circulation and habitat' (p. 73).

Overall, this is a welcome addition to Lefebvre's work available in English. As the most comprehensive translation of his studies of time and rhythm so far, it will be of very wide interest. Yes, Lefebvre's writing can be infuriatingly hard to follow, and repays substantial effort, concentration and revisiting. But this work on time is remarkably transdisciplinary and, correspondingly, there is something here for anyone interested in time, irrespective of disciplinary perspective. Whoever we are, Rhythmanalysis will enrich our theoretical and empirical investigations of time.

\section{Dave Horton, Lancaster University, $U K$}

Sandy Torres, Travels in Time, in Fiction and in Science. Paris: L'Harmattan, 2004. ISBN 2-7637-8069-5.

According to a recent poll in The Guardian (htpp://film.guardian.co.uk) scientists' favourite science-fiction (SF) films are, in order, Blade Runner, 2001: A Space Odyssey and the trilogy of Star Wars. Magnetic Tarkovski's Solaris and other famous movies follow in the list. The reasons of this choice, according to physicists and biologists, must be found in the way these films use science as an integral part of their narrative, making difficult concepts understandable and helping new theories to penetrate common people's imagination and language. This is also the idea of sociologist Sandy Torres, who researched science-fiction films, focusing on time.

'Science-fiction films and the knowledge of time' form the central focus of this compelling book which examines and analyses more than 150 films, with the author undertaking more than a quarter of this work. The first part of the volume deals with the most relevant ideas of time in philosophy, in physics, in sociology, in narratology, discussing ancient sources, classical metaphors of time and the contemporary state-of-the-art. While there are some significant omissions, such as details of the work of J. T. Fraser and Paul Davis, the author provides a clear engagement with competing definitions in this huge and interdisciplinary field. 